\title{
Perencanaan Komunikasi Krisis di Bengkel Har's Motor Sukabumi
}

\author{
https://doi.org/10.25008/parahita.v2i1.52 \\ Mohammad Shihab, Mikhail Kirtan \\ President University \\ Jl. KH Dewantara, Mekarmukti, Cikarang Utara, Bekasi 17530 - Indonesia \\ Email Korespondensi: shihab@president.ac.id
}

\begin{abstract}
Abstrak - Tidak ada perusahaan yang kebal terhadap krisis. Krisis dapat menimpa perusahaan, baik skala besar maupun skala kecil. PT Har's Motor adalah sebuah perusahaan otomotif yang melayani jasa modifikasi motor dan menyediakan spare part di Sukabumi. Untuk mempersiapkan krisis yang sewaktu-waktu terjadi, tim peneliti menyiapkan tiga skenario krisis yang berpotensi terjadi di perusahaan, yakni kecelakaan kerja, penularan penyakit, dan kebakaran. Kegiatan ini dilakukan untuk membantu PT Har's Motor untuk mempersiapkan diri menghadapi krisis sebelum krisis yang sebenarnya terjadi.
\end{abstract}

Kata kunci: Perencanaan krisis, manajemen krisis, Har's Motor, Sukabumi

\section{PENDAHULUAN}

Tench \& Yeomanz (2006) mendefinisikan krisis sebagai sebuah peristiwa yang dapat mengganggu operasional bisnis sebuah perusahaan. Dalam dunia kehumasan, krisis ibarat sebuah "virus" yang dapat masuk melalui satu bagian tubuh organisasi, menjangkiti perusahaan secara menyeluruh hingga sakit, dan berpotensi menular ke perusahaan lainnya.

Krisis dapat terjadi di perusahaan apapun tanpa memandang jenis usaha, lokasi geografis, dan skala bisnis (Wahdaniah \& Wahid, 2020). Krisis dapat disebabkan oleh kesalahan manusia, kejadian alam, atau kecelakaan (Setiawan, Kurniawati, \& Saputro, 2019). Krisis tidak dapat dihindari, tetapi dapat diantisipasi dampaknya. Yang terpenting adalah kesiapan perusahaan dalam menghadapi situasi (Tench \& Yeomanz, 2006). Salah satu caranya adalah dengan merencanakan komunikasi krisis.

Komunikasi krisis menjadi bagian dari manajemen krisis yang bertujuan untuk mengatasi krisis dengan cepat, menekan kerugian, dan memulihkan kepercayaan publik, citra, dan reputasi (Setiawan, Kurniawati, \& Saputro, 2019). Perencanaan komunikasi krisis dilakukan dengan mengidentifikasi potensi krisis, audit internal, perencanaan pesan, hingga evaluasi (Priscilla \& Lestari, 2019). Perencanaan krisis vital bagi sebuah bisnis karena krisis dapat terjadi tanpa gejala dan deteksi dini menjadi hal yang krusial, sehingga perusahaan harus menyiapkan perencanaan krisis. Hal ini pun menjadi penting bagi Har's Motor.

Har's Motor adalah sebuah perusahaan yang melayani jasa servis dan modifikasi motor di Sukabumi. Perusahaan ini juga menyediakan berbagai variasi onderdil dan spare part khusus motor. Har's motor memiliki komunitas pelanggan yang loyal. Di pasar daring, kualitas Har's motor termasuk sangat baik dan mendapatkan rating 4,2 dari 5,0 (Har's Motor, n.d.). Kualitas ini tentu harus dipertahankan agar pelanggan terjaga dan bisnis dapat terus beroperasi.

Sebagai entitas bisnis, Har's Motor juga harus bersiap untuk menghadapi kriyang sewaktu-waktu dapat terjadi. Oleh sebab itu, kami menyiapkan perencanaan komunikasi krisis yang sewaktu-waktu dapat digunakan oleh para personel Har's Motor.

\section{METODE PELAKSANAAN}

Kegiatan perencanaan komunikasi ini dilakukan dengan beberapa tahap. Tahap pertama, tim melakukan riset di lokasi untuk mengidentifikasi isu dan bibit krisis yang mungkin terjadi di Har's Motor. Tim mewawancarai pemilik dan sejumlah karyawan untuk memetakan isu dan potensi krisis, dan sejumlah personel yang akan menjadi tim krisis.

Di tahap selanjutnya, tim menyusun langkah-langkah komunikasi krisis yang akan menjadi buku panduan bagi perusahaan. Buku panduan ini tidak hanya berisi prosedur penanganan, tetapi juga lengkap dengan direktori kontak penting, template rumusan siaran pers, pernyataan pers, dan referensi artikel.

Proses perencanaan komunikasi krisis ini turut didukung oleh mahasiswa Program Studi Ilmu Komunikasi President University lainnya, yakni: (1) Adinda Salkhia Berliani; (2) Adhitya Engelbert Sumual; (3) Elvina Caroline Wiguna; (4) Felisia Rusli; (5) Fyrda Shafira; 
(6) Gracia Helene; (7) Natalia C. Mawey; (8) Natasya Aline Limarga; (9) Putri A. M. J. Lesomar; (10) Stevi Priskila.

\section{HASIL DAN PEMBAHASAN}

Har's Motor adalah sebuah perusahaan di bidang otomotif yang saat ini fokus pada jual beli suku cadang, servis, modifikasi, dan perakitan motor di daerah Sukabumi, Jawa Barat. Perusahaan ini ingin menjadi bengkel umum terbaik dan terlengkap yang menjadi pilihan utama masyarakat, khususnya di wilayah Sukabumi untuk melakukan perawatan dan perbaikan sepeda motor.

Sebagai sebuah entitas bisnis, Har's Motor tentu tidak ingin mengalami krisis. Namun, krisis dapat terjadi di setiap perusahaan dan dapat mengganggu performa bisnis dan merusak citra sebuah perusahaan. Bahkan, tidak sedikit organisasi yang harus gulung tikar setelah dihantam krisis. Oleh sebab itu, Har's Motor perlu mengembangkan perencanaan komunikasi krisis untuk mengantisipasi dampak krisis yang berpotensi terjadi di perusahaannya.

Perencanaan komunikasi krisis Har's Motor berisi strategi dan taktik komunikasi krisis yang dirancang untuk menekan dampak yang mungkin timbul dari sebuah peristiwa krisis. Panduan tertulis disiapkan untuk mempersiapkan setiap personel untuk menghadapi krisis yang sewaktu-waktu dapat terjadi.

\section{Tim komunikasi krisis}

Har's Motor telah menyiapkan dan menugaskan karyawannya untuk menjadi bagian dari crisis team. Seluruh karyawannya dibagi menjadi beberapa kelompok, seperti juru bicara, humas, pembukuan, dan operasional. Pemilik bengkel akan bertindak sebagai juru bicara utama ketika terjadi sebuah peristiwa. Humas akan menyalurkan informasi yang relevan diketahui oleh tim krisis dan publik eksternal. Sementara itu, tim pembukuan akan mencatat hal-hal yang berkaitan dengan keuangan dan tim operasional sebagai pelaksana teknis dan operasional bengkel.

Sebagai sebuah perusahaan, Har's Motor memiliki publik yang dapat terpengaruh oleh isu dan krisis. Dalam perencanaan komunikasi krisis ini, publik yang menjadi audiens sasaran adalah para konsumen, pelanggan, dan supplier.

Untuk menjangkau audiens sasaran, perusahaan ini telah mengidentifikasi media yang akan digunakan sebagai saluran komunikasi perusahaan dengan audiens. Media tersebut adalah telepon, Whatsapp group internal dan komunitas bengkel, Facebook, dan Instagram.

\section{Skenario krisis}

Peneliti mengidentifikasi tiga potensi krisis yang paling mungkin terjadi di perusahaan ini, yaitu kecelakaan kerja fatal, penyebaran penyakit menular, dan kebakaran. Kecelakaan kerja sangat mungkin terjadi di perusahaan ini karena para karyawan bekerja dengan peralatan teknika dan mekanika. Potensi penyebaran penyakit menular teridentifikasi karena para karyawan bekerja dalam luas lingkungan kerja yang terbatas. Selain itu, kasus kebakaran juga dapat terjadi sewaktu-waktu karena inti bisnis dari perusahaan ini adalah reparasi kendaraan bermotor.

Kecelakaan kerja karena kelalaian mekanik. Kecelakaan kerja adalah jenis kecelakaan yang terjadi di dalam lingkungan kerja. Kecelakaan kerja dapat terjadi karena lingkungan kerja yang tidak aman atau karena faktor kelalaian manusia (Restuputri \& Sari, 2015). Kecelakaan kerja di Hars Motor dapat menimpa karyawan dan pelanggan.

Sebelum terjadi krisis, Har's Motor harus menjelaskan tugas dan peran masing-masing personel yang menjadi tim krisis. Kemudian, perusahaan menentukan publik mana saja yang akan menerima informasi dan media apa yang akan digunakan. Untuk berkomunikasi dengan publik, perusahaan perlu menyiapkan template press release dan pernyataan resmi yang mudah digunakan sewaktu-waktu dengan usaha yang minimal.

Ketika terjadi kecelakaan kerja yang fatal, pengelola wajib memberikan pertolongan pertama sesegera mungkin dan membawa korban ke rumah sakit terdekat. Oleh sebab itu, penting bagi perusahaan untuk mengidentifikasi klinik, puskesmas, serta rumah sakit terdekat yang dapat dijangkau dengan cepat. Selain itu, perusahaan wajib mendampingi korban, berkoordinasi dengan pihak keluarga korban terkait kondisi dan biaya perawatan, dan mengetahui perkembangan kesehatan korban. Hal ini perlu dilakukan sebagai bentuk tanggung jawab perusahaan terhadap korban.

Upaya menjaga citra, perusahaan perlu menyiapkan pernyataan resmi tentang peristiwa kecelakaan kerja. Pernyataan resmi ini berisi kronologi kejadian, tindakan apa yang telah 
dilakukan, dan bagaimana tanggung jawab perusahaan terhadap korban kecelakaan. Pernyataan resmi disebarkan dalam bentuk siaran pers bilamana situasi telah menjadi konsumsi publik secara luas. Bila korban meninggal dunia, perusahaan perlu berkonsultasi dengan pengacara untuk mengantisipasi adanya tuntutan hukum.

Sebagai upaya pencegahan, perusahaan perlu menentukan area-area di lingkungan kerja yang rawan terjadi kecelakaan. Di area-area inilah rambu-rambu peringatan dipasang untuk mencegah terjadinya kecelakaan.

Salah satu bentuk upaya komunikasi yang dapat dilakukan untuk menangani krisis yang terjadi adalah dengan menyiapkan template pesan yang didistribusikan melalui pesan singkat sebagai berikut.

Kepada Bapak/Ibu pelanggan setia Har's Motor

Berkaitan dengan kecelakaan_ [jenis kecelakaan], kami memastikan bahwa pihak bengkel telah menangani kejadian ini dengan baik. Korban kecelakaan telah mendapatkan penanganan terbaik dan Har's motor akan meningkatkan kualitas mekanik dengan mempekerjakan mekanik berpengalaman serta akan melakukan pelatihan khusus. Har's Motor juga akan memberikan diskon untuk pelayanan service dan modifikasi khusus untuk pelanggan setia.

Kepuasan anda, prioritas kami. Terima kasih.

\section{[Nama Pemilik]}

Penularan penyakit antar manusia di dalam lingkungan bengkel. Penularan penyakit dapat dideteksi dari para pegawai yang mengalami gejala sakit yang sama. Untuk mengantisipasi hal terburuk, para pegawai harus diberikan izin untuk segera berobat ke fasilitas kesehatan terdekat atau yang telah ditunjuk oleh perusahaan. Perwakilan perusahaan perlu mengunjungi pasien terdampak untuk menunjukkan kepedulian perusahaan.

Sebagai langkah komunikasi awal, tim humas perlu mengumpulkan fakta-fakta sebelum menyiapkan pernyataan resmi perusahaan. Keterangan hasil diagnosa dokter dapat menjadi fakta penting untuk mengetahui penyebab kejadian dan disampaikan melalui pernyataan perusahaan

Upaya pencegahan perlu dilakukan untuk menghindari risiko penularan. Perusahaan dapat melakukan edukasi kesehatan dan disinfeksi di dalam lingkungan perusahaan. Disinfeksi ini dapat dilakukan secara mandiri maupun bekerja sama dengan organisasi lain. Edukasi kesehatan ditujukan kepada publik internal maupun eksternal yang berada di dalam lingkungan perusahaan. Edukasi yang dapat dilakukan seperti penggunaan masker, penggunaan handsanitizer atau fasilitas cuci tangan yang tepat. Selain itu juga, perusahaan perlu memfasilitasi para pegawainya dengan fasilitas asuransi untuk mengantisipasi tingginya biaya kesehatan.

Kepada Bapak/Ibu pelanggan setia Har's Motor,

Terkait informasi yang beredar tentang penularan penyakit di bengkel Har's Motor, kami akan menutup bengkel sementara waktu untuk sterilisasi dan akan beroperasi kembali pada__ _hari, tanggal]. Selain itu, Har's Motor juga akan memberikan diskon untuk pelayanan service dan modifikasi khusus untuk pelanggan setia. Oleh karena itu, dimohon kerja sama dari Anda untuk selalu menjaga pola hidup bersih dan sehat.

Kepuasan anda, prioritas kami. Terima kasih.

\section{[Nama Pemilik]}

Kebakaran. Peristiwa kebakaran sering terjadi secara tiba-tiba tanpa ada tanda-tanda. Har's Motor sebagai perusahaan dan juga bengkel menyimpan barang yang tentu sangat mudah terbakar sehingga perusahaan perlu menyiapkan langkah-langkah antisipatif.

Sebagai persiapan, setiap tim krisis wajib memahami peran dan tugas masing-masing bila terjadi peristiwa kebakaran. Selanjutnya, mengidentifikasi dan menyiapkan nomor penting yang wajib dihubungi saat terjadi kebakaran, yaitu pemadam kebakaran, kepolisian, dan rumah sakit yang paling dekat dengan lokasi perusahaan. Hal ini penting untuk memudahkan penanganan kebakaran dan juga penanganan apabila terdapat korban luka dan korban jiwa. Terakhir, menyiapkan alat pemadam kebakaran ringan (APAR) yang ditempatkan di sudut- 
sudut yang dekat dengan potensi sumber api dan mudah dijangkau.

Sebagai bentuk tanggung jawab, perusahaan juga dapat menanggung biaya pengobatan pegawai atau pelanggan yang menjadi korban luka dan korban jiwa sesuai undang-undang yang berlaku.

Setelah terjadi peristiwa, perusahaan wajib mengeluarkan pernyataan awal resmi tentang peritiwa yang meliputi ringkasan kronologis peristiwa, jumlah korban dan status penanganannya, apa yang telah dilakukan oleh perusahaan, dan apa yang selanjutnya akan dilakukan oleh perusahaan. Pernyataan ini disebar melalui saluran-saluran komunikasi yang dimiliki oleh perusahaan, seperti contoh sebagai berikut.

[Salam]

Telah terjadi peristiwa kebakaran di bengkel Har's Motor pada Thari, tanggal, pukul). Kebakaran menyebabkan_ [jumlah] orang terluka dan sedang dalam perawatan di RS [nama rumah sakit]; dan_[jumlah] orang meninggal dan saat ini sedang dalam proses peristiwa ini. . Kami sangat prihatin atas

Kami telah berkoordinasi dengan pihak-pihak terkait untuk mengetahui penyebab peristiwa ini dan telah menghubungi pihak keluarga korban untuk penanganan lebih lanjut.

Kami secara terbuka akan terus berkoordinasi dan bekerja sama dengan pihak-pihak terkait dan juga kepada keluarga korban sebagai bentuk tanggung jawab kami, hingga permasalahan ini selesai.

Terima kasih.

Nomor telepon darurat. Tim telah mengidentifikasi instansi-instansi terkait yang dapat membantu Har's Motor dalam penanganan krisisnya. Nomor-nomor tersebut antara lain:

Tabel 1. Nomor Kontak Darurat

\begin{tabular}{|l|c|}
\hline \multicolumn{1}{|c|}{ Instansi } & Nomor Kontak \\
\hline Pemadam Kebakaran Kota Sukabumi & $(0266) 222155$ \\
\hline Polisi & 110 \\
\hline Ambulans & 118 \\
\hline Polres Sukabumi & $(0266) 6248110$ \\
\hline Polsek Cikole & $(0266) 215785$ \\
\hline RSUD R. Syamsudin S.H & $(0266) 225180$ \\
\hline RSUD Pelabuhan Ratu & $(0266) 432081$ \\
\hline RSUD Sekar Wangi & $(0266) 531261$ \\
\hline RS Betha Medika & $(0266) 248002$ \\
\hline RSI Assyifa & $(0266) 222663$ \\
\hline RS Hermina & $(0266) 6252525$ \\
\hline RS Kartika Medical Centre & $(0266) 625090$ \\
\hline
\end{tabular}

\section{KESIMPULAN}

Merencanakan komunikasi krisis penting bagi sebuah bisnis, termasuk Har's Motor. Perencanaan komunikasi krisis yang telah kami siapkan melalui sejumlah tahapan, yakni riset dengan observasi dan wawancara, dan eksekusi penyusunan buku panduan komunikasi krisis. Hasil riset menemukan sejumlah bibit krisis yang potensial terjadi, yaitu kecelakaan kerja, penularan penyakit, dan kebakaran.

Setiap potensi krisis yang telah teridentifikasi, kami menyiapkan skenario krisis dan rencana pesan, dan saluran-saluran komunikasi yang dapat menjangkau publik kunci Har's Motor.

\section{Daftar Pustaka}

Har's Motor. (n.d.). Har's Motor. Retrieved from Tokopedia: https://www.tokopedia.com/harsmotor 
Priscilla, J., \& Lestari, P. (2019). Model Komunikasi Krisis Pelayanan Pasien di Rumah Sakit Umum Daerah. Jurnal Ilmu Komunikasi, 17(1), 39-50. Retrieved from http://jurnal.upnyk.ac.id/index.php/komunikasi/article/viewFile/3509/2674

Restuputri, D. P., \& Sari, R. P. (2015). Analisis Kecelakaan Kerja dengan Menggunakan Metode Hazard and Operability Study (Hazop). Jurnal Ilmiah Teknik Industri, 14(1), 2435. doi:10.23917/jiti.v14i1.621

Setiawan, T., Kurniawati, J., \& Saputro, E. (2019). Komunikasi Krisis di Era Digital. Intelektiva: Jurnal Ekonomi, Sosial \& Humaniora, 1-11.

Tench, R., \& Yeomanz, L. (2006). Exploring Public Relations. Harlow: Prentice Hall.

Wahdaniah, I., \& Wahid, W. (2020). Strategi Manajemen Krisis Public Relations TNI Angkatan Laut dalam Menghadapi Pandemi Covid-19. Warta Ikatan Sarjana Komunikasi Indonesia, 160-167. doi:https://doi.org/10.25008/wartaiski.v3i02.72 